\title{
MOSTLY UNKNOWN BUT STILL PROFITABLE: THE LOHN SYSTEM IN THE NORTH-EST REGION OF ROMANIA
}

\author{
Nichifor Bogdan Vasile \\ Vasile Alecsandri University of Bacău \\ bogdan.nichifor@ub.ro \\ Zaiț Luminița Iulia \\ Vasile Alecsandri University of Bacău \\ zait.luminita@yahoo.com
}

\begin{abstract}
The garment manufacturing sector (and, implicitly, knitwear) was one of the most important areas of the Romanian economy during the communist era, satisfying a large part of the existing demand, both in the domestic market and at the external ones. By making a statistic untill the year of 1989, we note that this sector occupied about 10\% of Romania's industrial output, 30\% of the country's exports and $20 \%$ of the number of employees in industry. After 1989, this industry experienced several stages of development, but also stagnation due to the conjuncture that the Romanian economy crossed. Currently, the knitwear market in Romania is dominated by legal entities that carry out lohn production activities at the expense of own brand production, the factors favoring this reality being: relocation of lohn businesses from China to countries like: Romania, Morocco, Tunisia, Turkey, Hungary etc .; high attractiveness of the lohn production system for domestic legal entities, both from an economic perspective and from the perspective of constancy of orders; and so on. This article wishes to highlight the current situation in the knitwear sector in the Northeast Region of Romania, namely the trends from the perspective of the local legal entities working on the lohn production system.
\end{abstract}

\section{Keywords}

production in lohn system; the knitwear market; internal rivalry; relocation of lohn system activities; the power of suppliers and buyers; marketing strategies

\section{JEL Classification}

M30

\section{The size of the knitwear market in the North-East Region}

According to the latest statistical data available in the North-East Region in the year 2015, the specific market for NACE code 1439 The manufacture by knitting or crochet of other garments was represented by 52 units, representing $18.71 \%$ of the national active units.

The territorial distribution of the active national units reveals the tendency of concentration of the legal entities in the North-West (30.22\%), North-East (18.71\%) and Center (16.19\%) - Figure no. 1.

At the level of the North-East Region, most legal entities are located in Neamt County, with a considerable distance from it being Bacău and Iaşi counties - figure no. 2. The concentration trend of the legal entities in Neamt county $-63.46 \%$ of the local active units, originates in the sector tradition in this area, where some of the most famous and old knitwear brands was founded (eg SC EMA S.A.). 


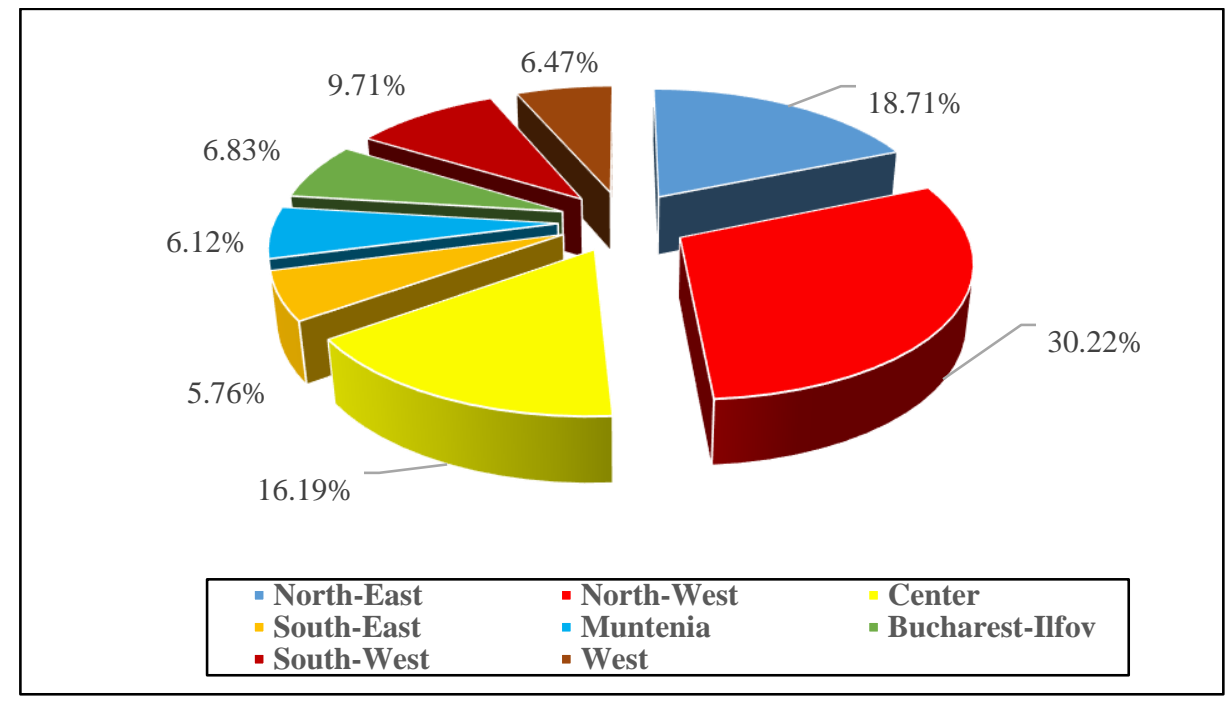

Figure 1 Distribution of active units with NACE code 1439 Manufacture by knitting or crocheting of other garments by regions of development in Romania

Source: data taken from www.insse.ro and processed by authors

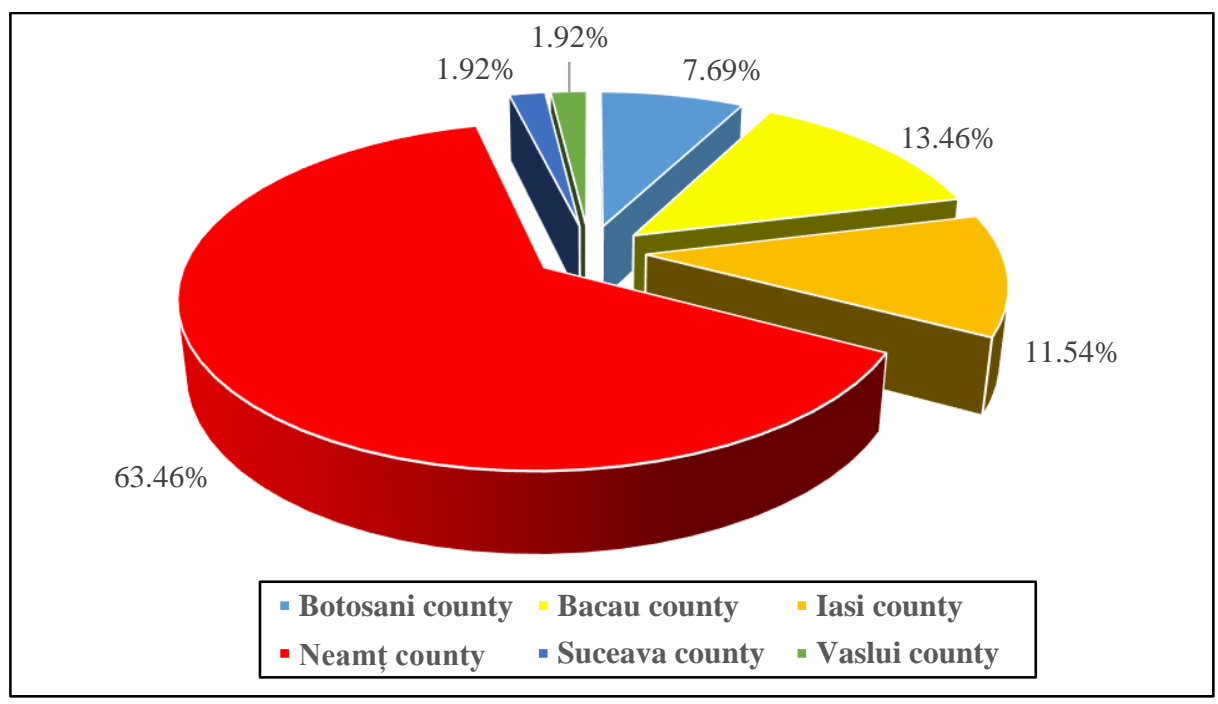

Figure 2 Distribution of active units with NACE code 1439 Manufacture by knitting or crocheting of other garments on the counties of the North-East Region

Source: data taken from www.insse.ro and processed by authors

Of the total regional units in the year 2015, 55.77\% were micro-enterprises, $28.85 \%$ small enterprises, $11.54 \%$ medium-sized enterprises and only $3.85 \%$ large companies. This structure reveals both the development trend of the SME sector in Romania and the particularity of the analyzed sector, the development of small production systems, most of them in the lohn system.

The dynamics of the indicator number of local units active in the North-East Region (Figure 3) reveals a relatively high degree of stability of the market, the annual oscillations in the number of inputs in / out of the sector being weak. In fact, although 
in 2015 as compared to 2010, the regional number of units increased by $8.33 \%$, only 4 new legal entities appeared in the sector. The average growth rate of the analyzed indicator was in the period 2010-2015 1.61\%, in which context we can estimate that the entry barriers on the market are high, there being factors that inhibit the access of the newcomers in the analyzed sector.

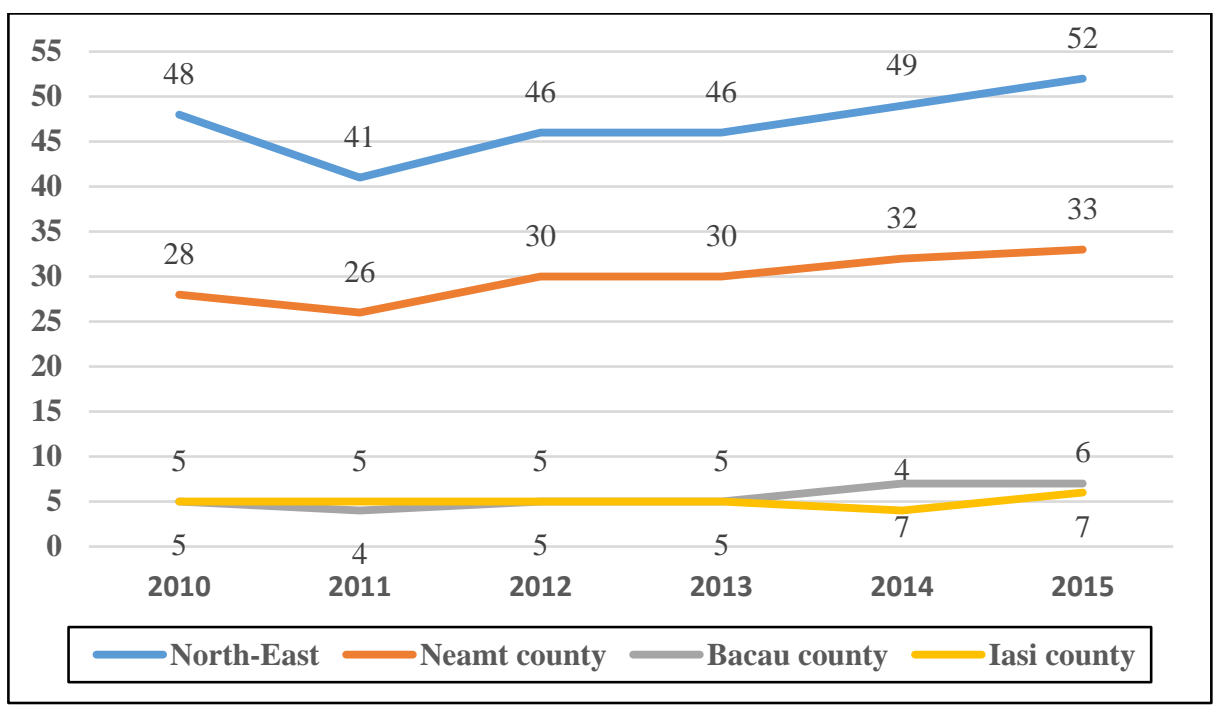

Figure 3 Dynamics of the number of local units active in the regional market specific to NACE code 1439 Manufacture by knitting or crocheting of other garments (2010-2015)

Source: data taken from www.insse.ro and processed by authors

To highlight the frequency of penetration in the sector, an analysis was made, from secondary data sources, of the year of setting up the 20 most important regional competitors. Of the 20 competitors considered in the analysis, $70 \%$ are over 10 years old in the sector and only $20 \%$ have an experience of less than 5 years.

In 2015, the turnover registered at the level of the national market related to the NACE code 1439 Manufacture by knitting or crocheting of other garments reached the maximum of 677.5 million lei, slightly decreasing compared to the previous year ($1.67 \%)$.

The regional turnover in the analyzed sector for the year 2015 was estimated at the top limit of 117.68 million lei, representing about $17.4 \%$ of the national indicator.

As can be seen throughout this article, many organizations have focused on rendering lohn production services, mainly serving external markets, a context in which we consider appropriate to include in analysis the indicator Export of articles and accessories clothing from knitwear (from the perspective of the methodology of the National Institute of Statistics, the value of the export includes also the lohn production activity).

According to the latest data available at innse.ro (tempo online), at the level of 2016, the export of knitwear articles and accessories made by the companies in the NorthEast Region reached the ceiling of 67112 thousand euro (the data are provisional). Compared to 2015 (export value 67062 thousand euro - semi-final data), in 2016 there was a slight decrease in the export of articles and accessories of knitwear (-0.07\%). 
Export distribution in the North-East Region per months in 2016 (Figure 4) reveals a relative stability of external demand for the product category and clothing accessories from knitwear, the peak of orders being recorded in June And July.

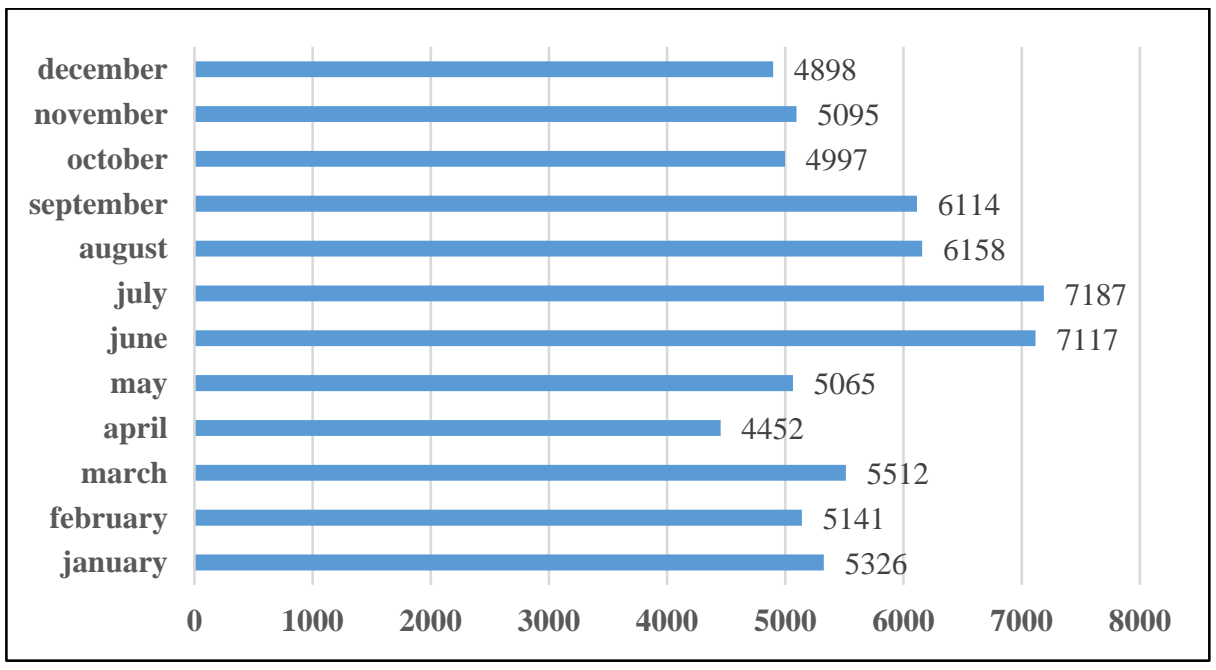

Figure 4 Distribution of exports of articles and clothing accessories from knitwear made in the North-East Region per months in 2016 (thousand lei) Source: data taken from www.insse.ro and processed by authors

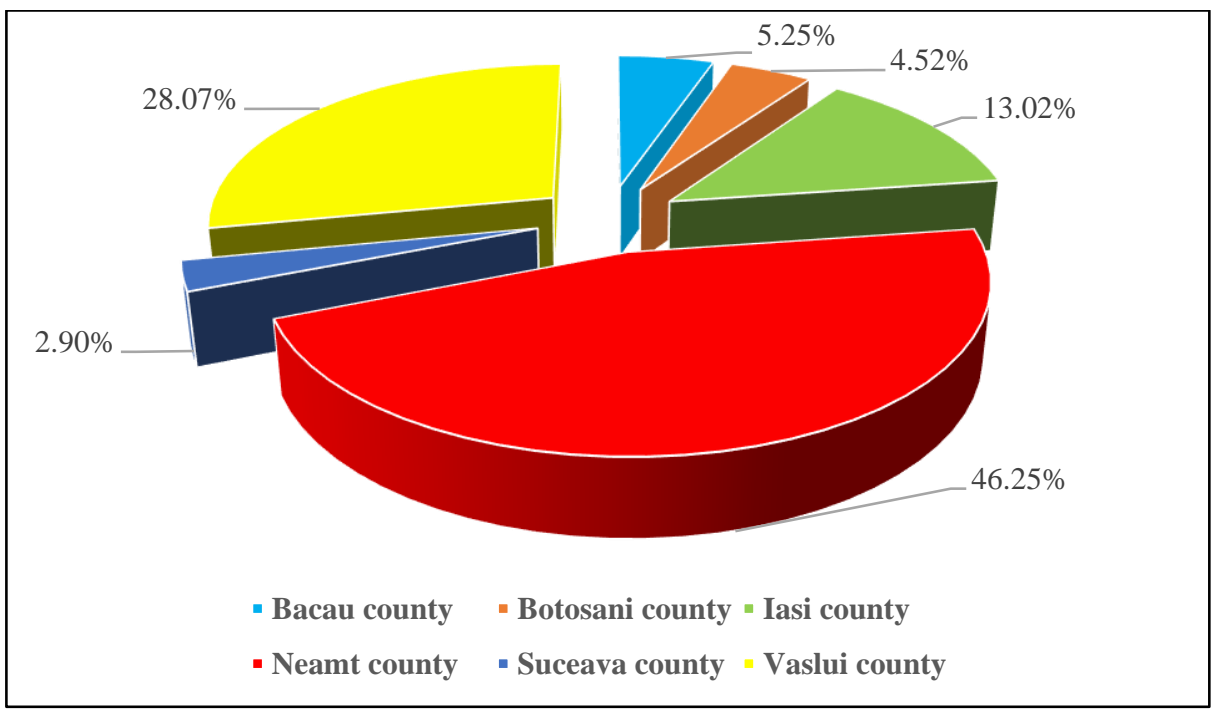

Figure 5 Distribution of exports of knitted garments and accessories made in the North-East Region, at the level of 2016, by component counties

Source: data taken from www.insse.ro and processed by authors

According to the distribution of clothing and clothing accessories made from knitwear made in the North-East Region at the level of 2016, by component counties (Figure 5), Neamt County had the most intense activity on foreign markets, its share in total the analyzed indicator exceeds $45 \%$. 


\section{Particularities of the knitwear market in the North-East Region}

An analysis from external sources such as web sites and business directories has allowed us to identify a number of peculiarities of the knitwear market in the North East Region as follows:

- the trend of large-scale development of lohn production activities at the expense of own brand production.

Of the 20 regional units analyzed, $60 \%$ provide lohn production services for customers located primarily in foreign markets, $30 \%$ combine the production of own brands with the production of lohn production services and only $10 \%$ of the entities analyzed can boast of their own production system.

The production of lohn production services involves, from the perspective of the contractor, the realization of finished products or their components, upon the firm's ordering of a customer, on the basis of the technical specifications, of the raw materials, the materials, the accessories and the patterns provided by him. Practically, lohn contracts only involve the use of technical capital and labor within the local firm.

The supply of lohn production services experienced an explosive growth in the clothing and knitwear sector in Romania, both due to the undeniable advantages in terms of poor fluctuations in the volume of orders and implicit sales, and due to the decrease in the interest of Romanian consumers for knitwear, and the fierce competition from substitute products, particularly those imported.

- the tendency of local operators to subcontract, to other local firms, a variable volume of external orders or stages in the production process.

Many regional regional operators, which have a high reputation in foreign markets, honor a number of external orders by resorting to subcontracting to production services provided by other local competitors. There have been many situations in which domestic firms have not refused orders in foreign markets, even if their production capacity would not have allowed them to be honored in time, because of their subcontracting, especially to local partners. In other words, within the framework of the market, the classic competitive relationships have turned into cooperation relations, this fact being due to the concentration of each local operator on 1-2 external outlets and 35 external customers, at lower limits. Also, there are often situations in which only certain stages of the production process are subcontracted to local partners (eg product finishing, finished product assembly, product accessory, product packaging, etc.).

- developing lohn production activities for customers located in foreign markets. The most preferred markets for lohn service providers are: Italy, Great Britain, Spain, Germany, France, etc.

- the tendency of the regional operators to develop long-term partnerships with a limited number of clients, in which the dependence on the volume sources (customers) is accentuated.

- splitting the profile market into two broad categories of operators: organizations that develop integrated production streams (knitting, cutting, fabrication, finishing) and specialized organizations at certain stages of the production process;

- the tendency to continuously diversify the portfolio of services (many profile operators are focused on the permanent increase of technical capital, especially with machines that offer the possibility of obtaining different variants of finesse).

- the sector of activity is dominated by micro-enterprises and small enterprises, predominantly those with local capital;

- the targeting of a small number of domestic operators towards the creation of own brands for the domestic consumer market; 
- numerous specialized organizations have developed and implemented projects to access European funds to obtain funding aimed at increasing technical capital and labor (creation of new jobs);

- the profile market is polarized, with the top 3 companies accounting for over $45 \%$ of regional turnover. Market dominance by a single unit is found in Bacău County, where a single organization owns over $80 \%$ of county turnover;

- the turnover of the first 3 competitors of the regional market was in the range of 11.4 - 23.6 million lei in 2015.

In the context of this analysis, it should be noted that, especially in the case of organizations exclusively focused on the production of lohn knitwear, the maneuvering space is extremely limited in terms of the possible marketing actions, as follows: the company does not own a portfolio of products, but only produces services; does not own its own brands, the tendency being to ignore the domestic consumer market; they practice tariffs for the provision of the production services in the interval negotiated with the different categories of external clients; does not own a channel/network of distribution; does not carry out extensive promotional actions, the most common tools being internet advertising (web site or business directories); participating in international fairs; sales force (the operationalization of small-sized teams that have the role of market prospecting).

\section{Influencing factors in the knitwear sector in the North-East Region}

Considering the particularities of the knitwear market in the Northeast Region mentioned above, this article aims to identify the factors that favored the current configuration of the sector.

Without claiming an exhaustive analysis, the following factors of influence can be identified:

- relocation of lohn business, starting in 2010, from China to countries such as Romania, Morocco, Tunisia, Hungary etc.

According to sources like www.expansion.com, as of 2010, lohn clothing production in China has proven to be no longer profitable for major fashion companies, with multiple reasons:

$\checkmark$ Even if the costs in China have increased, it seems that this was not the main problem of the big producers. The main drawback was related to the time span, which is extremely high, between supplying inputs and outputs. Basically, according to the available data, this range was somewhere in 3-4 months, the impact on the shelf speed being a disastrous one. In this context, large manufacturers of clothing preferred to sacrifice lower labor costs in favor of shelf-life (the logistics chain being shortened from 5-6 weeks to 3-5 days), a fact that favored the return of the lohn system to the countries of Eastern Europe;

$\checkmark$ Another reason behind the lohn withdrawal from China was the fact that Chinese producers have limited their export capacity and have not received any big orders as a result of the increase in consumption in the domestic market;

$\checkmark \quad$ In the same direction of relocation reasons, it can also be mentioned mass migrations from the textile industry to sectors offering better remuneration and flexible working conditions;

$\checkmark$ Another reason was the desire of the producers to reduce the unfavorable impact of the exchange rate, as trading operations were then affected by tensions between yuan and dollars;

$\checkmark$ The reasons for the return of the lohn system in Romania, mentioned by most of the foreign producers, were: quality of service; high delivery speed with 
favorable impact on shelf-life; lower costs compared to the rest of Europe.

Obviously, beyond the reasons that led to the choice of Romania by the foreign partners as the preferred location for the development of lohn production, the factors that led to the current configuration of the sector must be identified, namely:

- the opening of the local profile operators to the cooperation with the foreign markets, in the context of falling domestic demand for knitwear products;

- the development of the lohn production system has helped to increase the attractiveness of the analyzed sector, favoring the expansion of the SME sector. Sector penetration proves to be relatively easy from the perspective of regulations, but real barriers are: high level of investment, especially in the case of the development of an integrated production stream; the effect of experience, which is the prestige of the big companies, with a long standing in the sector; access to foreign markets, etc.

- Tradition in the sector and the existence of a human capital prepared in the field favored the large-scale development of the lohn production system, Romania being preferred by external operators;

- the level of minimum and average wages was the ground for rapid development of lohn production, with labor costs being considered extremely low by external operators. In this context, it should be specified that the $16 \%$ increase in the minimum wage from February 1, 2017, generates an increase in production costs in the case of domestic operators. In this context, there are at least two risk ranges: either lohn production service tariffs are increased, with the risk of reallocating business by external customers to cheaper labor countries; or attempting to maintain relatively constant tariffs, with an impact on the profit of domestic service providers for lohn production.

- trade liberalization in the textiles and clothing sector (implicitly knitwear) has stimulated the rapid penetration of the market by foreign operators;

- the support by the Romanian state, through various measures, of the human resources qualification in the analyzed sector has stimulated both the expansion of the number of active units and the penetration of new foreign markets by the domestic operators;

- Romanian and European legislation support inter-community exchanges through financial facilities.

\section{Advantages and disadvantages of the lohn production system}

The widespread expansion of lohn activities generates both advantages and disadvantages within the analyzed sector. Obviously, the advantages and disadvantages of the development of lohn production systems are manifested both at the macroeconomic and microeconomic level.

From a macroeconomic perspective, the most important advantages are: a surplus of demand in foreign markets, with a favorable impact on domestic output, exports and unemployment rates (reduction); improving inter-communal relations, and beyond; creating a favorable image at the level of foreign markets, thanks to tradition and experience in the sector; the possibility of expanding the lohn production system and other spheres in the manufacturing industry, etc.

From a microeconomic perspective, the most important advantages of lohn production development are:

- the certainty of domestically-owned producers of contracts and a weakly fluctuating demand;

- relief from the responsibility of purchasing raw materials, materials, accessories, etc.

- eliminating the difficulties involved in creating an outlet or penetration 
network within certain outlets;

- elimination of the risk of not realizing production or obtaining weak indicators regarding the sales process;

- minimizing the effort towards market research in order to align with the trend of fashion;

- elimination of tasks of generating creative patterns;

- ppresence in different foreign markets, difficult to penetrate with own products (direct export);

- $\quad$ significant potential to attract new external customers (without significant market prospecting efforts), thanks to the recommendations made by actual customers.

On the other hand, the inconveniences of the lohn production system must also be mentioned. At both macroeconomic and microeconomic level, since lohn activity involves only the workforce in host countries, with production costs being significantly reduced for the beneficiaries, the export of own brands is limited. From a microeconomic perspective, one should mention the disadvantage related to the loss of the domestic producers' connection with the domestic consumption market.

\section{Conclusions}

Although the knitwear market in the North-East Region seems to be a highly competitive one from the point of view of the local active units, named by Michael Porter (1985) as its internal rivalry, its current configuration (the concentration of a large share of legal entities on production services in the lohn system, the orientation of the organizations on 1-2 external markets and 3-5 corporate clients, the tendency to subcontract to the local partners a volume of the orders obtained in the foreign markets, etc.) allows us to appreciate that one of its most prevalent features is related to the development of collaboration relationships between local producers, to the detriment of classical competition relations.

As can be seen from the previous analysis, the production of lohn production services has grown sharply in the knitwear sector in the North-East Region, both because of alignment with the national trend - the national clothing and knitwear sector folded better on the particularities of the lohn system activity and as a result of the opening of the legal entities in the analyzed area to this type of activity. Obviously, the reasons for rapid acceptance and assimilation of this system stem from the many advantages provided by its operationalization, especially as domestic demand for knitwear products has experienced some regression.

From the perspective of the above-mentioned factors of influence, we tend to appreciate that, in the short and medium term, despite the increase in the minimum wage in the economy, we will not see any relocation of lohn activities, the Romanian sector being extremely attractive to companies in the foreign markets.

\section{References}

Brătucu, G., Epuran, Ghe., Gârdan, D.A., Bubmas, F., Zamfirache, A. (2017), The evolution of textile and clothing industry in Romania: an analysis form the perspective of imports and exports determinants, Industria textilă, vol. 68, no.2, $147-155$.

Florin, B.I. (2009), Features of the international system of production in textiles and clothing industy in Romania, Managerial Challenges of the Contemporay Society, Proceedings, 178-181.

Hooley, G. J., Saunders, J. A. (1993), Competitive Position: The Key to Market 
Strategy, London, Prentice Hall International

Lambin, J-J. (1994), Le marketing strategic (third edition), Paris, Ediscience International.

Lambin, J. J, Chumpitaz, R., Moerloose, Ch. (2005), Marketing strategique et operationnel. Du Marketing a l'orientation marche, Paris, Dunod..

Lendrevie, J., Lindon, D. (1997), Mercator. Theorie et pratique du marketing (5-th edition), Paris, Dalloz.

Porter, M. E. (1985), Competitive Advantage, New York, The Free Press.

Pickles, J., Smith, A. (2011), Delocalization and Persistence in the European Clothing Indusrty: The Reconfiguration of Trade and Production Networks, Regional Studies, vol. 45, 167-185.

Tedlow, R., Abdelal R. (2004), Theodore Levitt's ,,The Globalisation of the Markets: An evaluation after two decades" in the Global Market: Developing a Strategy to Manage Across the Borders, Quelch, J.A., Deshpande R., New Jersey, John Wiley Sons. 